\title{
BILINGUALISM AS A PHENOMENON OF TRANSCULTURAL COMMUNICATION IN FOREIGN LANGUAGE TEACHING
}

\begin{abstract}
This research looks at the trends in the development of language education in the context of globalization and informatization of society and the linguistic interpretation of bilingualism in its broad and narrow understanding, the functional and speech formulating aspects of transculturalism. It should be noted that, under conditions of institutionally subordinate multilingualism, the features of teaching a foreign language are largely conditioned by the "dynamic" nature of the development of bilingualism.

Keywords: bilingualism; transculturation; globalization; language contacts; transcultural communication; foreign language teaching; multicultural model of education; intercultural model of education; transcultural model of education.
\end{abstract}

\section{Introduction}

Cultural and linguistic exchanges have existed at all times, but nowadays they acquire a special significance against the background of the globalization of the world society. Various linguistic and cultural contacts have become an everyday life phenomenon; international ties in politics, science, industry, art, culture, tourism and other spheres of public activity have been intensively deepening. These processes have led to the expansion of the boundaries of linguistic and cultural contacts. At the same time, people's mobility and their motivation for learning foreign languages, establishing and maintaining contacts within their own country and abroad have increased. "Indeed, in the present world, contacts between people of different cultures are becoming more and more multi-, rather than bilateral (in the political, professional as well as in the private sphere), but also the cultural configurations for an average individual become less permanent and more flexible, because of an increase in migrations and other kinds of mobilities, commonly multiple during a person's life-span" [1. pp. 124-125].

The 21 st century, as a century of active international, intercultural communication and exchange of information, poses new challenges for nations and states, and, in this context, overcoming language barriers is of paramount importance. The priority of integration in the new conditions requires at least a bilingual society, bilingualism is becoming one of the most important features of a modern person.

Being one of the peoples of the Soviet Union, the Armenians, due to various political, historical, geographical and other circumstances, were influenced by factors contributing to the spread of bilingualism. In multinational societies, the use of bilingual and multicultural teaching methods is seen as an effective mechanism for resolving ethnic conflicts. In this sense, since Armenia is mainly a mono-ethnic republic, the use of such educational models in Armenia at first glance is devoid of logic, and in our case it is simply absurd to discuss such issues. However, at the same time, Armenia is a multilingual society, since most of the population is bilingual. In addition to the aforementioned, representatives of culturally different regions constitute a significant part of the population, and minority cultures are recognized as an important component of Armenia's cultural diversity. The task of preservation and development of linguistic and cultural diversity predetermines the priority development of language education. However, the relevance of studying different foreign languages within the framework of language education is becoming more acute as there is a struggle for information ownership in the information space. The ability to work with information in their native and non-native languages gives a person an advantage in any field of activity.

Back in the 1930s-1940s, Armenia set the task to provide bilingual (multilingual) education at all levels. From Soviet times to the present, besides the mother tongue, two foreign languages - Russian and one of the European languages (English, German, French) - are taught in Armenian schools.

The teaching of any foreign language in Armenia - in a foreign language environment - has its own peculiarities, first of all, in relation to the fact that the studied language is detached from the environment of its direct functioning. The situation of learning a foreign language is close to abstract learning, i.e. in isolation from the environment of functioning. Under the conditions of modern life, speaking at least one foreign language of the international communication is rightly considered a necessary factor of a person's cultural development. Globalization processes and the tendency of their further development undoubtedly contribute to the growth of bilingualism.

The aim of this study is to reveal the trends in the development of language education in the context of globalization and informatization of society and the linguistic interpretation of bilingualism in its broad and narrow understanding, the functional and speech formulating aspects of transculturalism.

The object of the study is the relationship between bilingualism and transculturalism as the key concepts of modern contact linguistics in foreign language acquisition (Language contact occurs when speakers of two or more languages or varieties interact and influence each other. The study of language contact is called contact linguistics). The imaginative world in bilingual speech, based on the language resources of the two cultures, is compounded by specific discourses that are inherent in each of these languages. Under the influence of ethnic thinking which has been accumulated for the thousands of years of the "generic memory" of the people, associative images are created while switching to another language, associated with the binary representation of the perception of reality in different languages [2]. In this situation, there 
is a reception of a dual language image of the world, which is caused by the different coding of the two semiotic structural units.

The theoretical and methodological basis of the research is well-grounded on the works of D.S. Likhachev [3], G.D. Gachev [4], M. Epstein [5], M.V. Tlostanova [6, 7], B.A. Malinovski [8], V. Zamel [9], and others. They make it possible to reveal the multifaceted and controversial phenomenon of transcultural communication, its structure and mechanisms of functioning. A contribution to the understanding of the basics of human communication in society has been made by the theory of social action of Max Weber and Emile Durkheim. In understanding five essences of the phenomenon of communication, Georg Simmel's theory of social interaction has had a remarkable influence. This author introduced the concept of philosophical discourse interaction as the basis of communication involving the interaction and mutual influence of two or more subjects. However, the problem of correlation of transcultural communication and bilingualism in these studies is not fully developed, especially in the framework of understanding bilingualism as an aspect of transculturalism. In this study, the authors used the following research methods: classical methods of linguodidactics, pedagogy and linguistics, such as analogy, generalization and comparison; sociocultural, systemic, structural and functional methods; the comparative analysis of empirical and theoretical generalizations, as well as the methods of narrative analysis and description.

\section{Bilingualism, language contacts and language interaction}

The interest in the scientific research of bilingualism arose in the late 19th century. Foundations of the scientific development of the linguistic problems of bilingualism were pledged in the works by J. Baudouin de Courtenay, L. Shcherba, F. Fortunatov, A. Shakhmatov, E. Vereshchagin, A. Meillet, U. Weinreich, H. Schuchardt, E. Haugen, L. Bloomfield, and others. The term "bilingualism" was first introduced in 1938 by V. Avrorin, who defined bilingualism as "the same command of two languages". In other words, bilingualism begins when the degree of speaking the second language approaches close to the degree of speaking the first one [10. P. 51].

There are many definitions of bilingualism in linguistics. Some researchers refer to it as "the practice of alternating the use of two languages" [11. P. 3]; others define bilingualism as "speaking two languages and regular switching from one to another depending on communicative situations" [12. P. 3]; others consider it as "speaking two languages as native" [13. P. 3]. However, there are also other viewpoints on this issue. For instance, E. Haugen believed that in bilingualism the degree of proficiency of one language might be quite low [14. P. 61]. E. Vereshchagin defines bilingualism as the ability "to creatively construct one's speech belonging to the secondary linguistic system [15. P. 16]. M. Siguan and W. Makki propose "to call bilingual the person who apart from the own language to a comparable extent is proficient in another language, able to use any language with the similar efficiency under any circumstances [16. P. 11]. The most extensive definition of bilingualism was worked out by A. Schweitzer: "Bilingualism is coexistence of two characters in one linguistic (language) collective, which use these languages in different communicative spheres depending on the social situation and other parameters of the communicative act; both languages, serving for one collective, form a unified social and communicative system and functionally complement each other" [17. P. 111].

As can be seen from the definitions, the vast majority of experts admit the possibility of a broad understanding of this phenomenon, such as "... continuum extending from a very basic proficiency in contact language to a very complete and full proficiency" [12. P. 11]. A narrow understanding of bilingualism is reduced to equal proficiency in two languages [18. P. 137].

Meanwhile, in the definition of bilingualism some researchers do not restrict to two languages. According to $\mathrm{K}$. Myers-Scotton, bilingualism is the ability to use two or more languages sufficiently to be able to conduct a limited daily conversation [19. P. 16]. R. Appel and P. Muysken determine a bilingual individual as a person who regularly uses two or more languages alternately [20. P. 23]. Therefore, it is considered necessary to address the phenomenon of multilingualism (polylingualism), which means "the use of several languages within a certain social community (primarily the whole state); the use by an individual (group of people) of several languages, each of which is selected in accordance with a specific communicative situation. Both these phenomena, bilingualism and multilingualism, are interconnected and not rigidly determined" [21. P. 303].

Researchers believe that the phenomenon of bilingualism is multifaceted and that it is impossible to determine the dominant social science for studying it; therefore, it is possible to consider various types of this phenomenon. The aspects of bilingualism are examined in various social sciences. According to E. Vereshchagin, bilingualism in psychology appears as a mechanism for the production of speech; in linguistics it is learned in the framework of the theory of language contacts; in sociology the phenomenon of bilingualism is considered in the context of problems related to the behavior or place of the bilingual person in the society [15].

It can be stated that bilingualism occurs only upon contact of languages, which is preceded by the long coexistence of two nations speaking different languages.

Language contacts arise where two or more linguistic structures occur in the speech use. It is known that languages, like cultures, are rarely self-sufficient. "The needs of communication cause the speakers of one language to enter into direct or indirect contact with the speakers of neighboring or culturally dominant languages" [15. P. 173].

The issue of contact linguistics is based on the following main categories - language contact, bilingualism, adoption and interference, substratum and superstratum, convergence and divergence, code switching, pidgin and creole languages. Obviously, the concept of language contacts occupies a central place in the conceptual construct of contact linguistics.

The result of interaction of two or more languages is a change in one or all contacting languages. These language changes are called language interference (Burdeniuk \& 
Grigorevsky, 1978; Lafage, 1973; Vinogradov, 1983, 1990).

A special section of contact linguistics is a study of the origin and functioning of pidgins and creole languages (Bickerton, 1975; Chaudenson, 1988; Molodkin, 2001). Pidgin is a special language formation occurring in the context of establishing contacts between representatives of different language communities who do not have a common language, and therefore pidgin does not have a group of native speakers. The appearance and nativization of pidgin in contact linguistics is called creolization.

In the diachronic process all the languages are influenced by the neighboring languages. "Language contact is an extremely broad class of the language processes caused by the different kinds of interaction of the languages" [23. P. 178]. Changes caused by language contacts take place in the history of every language. Language development is impossible without the influence of the surrounding environment. Cross-language connections, which lead to the appearance of bilingualism, are established between native speakers of these languages. Native speakers of contacting languages can belong to different social and professional groups, ethnic cultures and are heterogeneous in demographic terms; therefore, a demographic factor should be considered in teaching languages at educational institutions. Thus, bilingualism calls in question the possibility of existence of a monolingual culture. In this sense, bilingualism raises concerns for the preservation of the native culture, and at the same time expands the cultural range, brings the experience of foreign communities speaking other languages. When it comes to a bilingual individual, it is necessary to mention not only the influence of two language systems on their thinking, but also the fact that the person is under the influence of two cultural systems forming their mentality. Becoming members of a language community, bilingual speakers learn to structure their own ideas, value system, experience and behavior in order to adjust to the cultural system of the group they want to join. "Since language is a means of expression of meaning, this meaning, at least to a certain extent, must be independent of language and transfer from one language to another. Meanwhile, this important characteristic of division - and divisibility - of meaning from language is often denied by researchers. Thus, the German philosopher of the 18th century J.G. Herder argued that thinking in its essence is identical to speaking, and therefore changes from language to language, and from nation to nation. "The human spirit, he wrote, thinks with words" [24. P. 185].

\section{The issue of transcultural communication and contemporary bilingualism}

The experience that a person acquires using one language is always different from the experience acquired from the use of the second language. The usual requirement for a bilingual person is the regular use of each of the languages and elements of culture in various types of activities, such as reading, writing, speaking, and listening comprehension of an interlocutor. Nevertheless, even similar good language and sociocultural competence of an individual does not guarantee the acquisition of the lan- guage for its use in each sphere of human activity. Most often, a person prefers to use different languages in different situations. For example, in situations related to learning and technical aspects of knowledge, preference will be given to one language, and in emotional or domestic situations to another one. A person understands humor, dialectal differences and folklore in one language, and jargon and modern literature in another language; it is much easier to read and write in one language, and easier to understand and speak in another one. This again proves that the coexistence of the two completely identical social spheres of the languages and cultures represented by them is impossible. In mutual language and cultural contacts, bilingual speakers are forced to either reject the other culture or adjust to the new conditions. Binary perception occurs in the mind of a bilingual person who collides with two cultures - their own and another. The binary culture of a bilingual person is being formed in this confrontation. The binary is manifested both in the unity of the two cultures and in their contradiction: texts (symbols) of the cultures (their own and another) are being opposed in the consciousness of a bilingual. At the same time they cannot exist without each other, they are in symbiosis since the bilingual speaker lives in an intermediate environment between the two cultures.

Communicative units of speech of a bilingual person can be understood not only as a result of a purposeful study of languages in the learning environment, but also as a result of unconscious (unfocused) acquisition and incidental learning in various informal spheres, and sometimes on the level of separate words or simple recognition.

Bilingualism is known to involve the use of other language for successful communication. However, such communication can occur not only in a foreign language, but also in the form of mixed language with other bilingual speakers within a given community. The second language as a component of bilingualism is almost not used by members of the given community for direct everyday communication.

The occurring integration processes separately influence each language, which develops under the impact of many external factors. The main factor is allocation and influence of another culture, when not only language units are accepted, but also their cultural components such as show, makeup, pub, shopping, etc. The imaginative world in bilingual speech, based on the language resources of the two cultures, is compounded by specific discourses that are inherent in each of these languages. Under the influence of ethnic thinking which has been accumulated for thousands of years in the "generic memory" of the people, associative images are created while switching to another language, associated with the binary representation of the perception of reality in different languages [2]. In this situation, there is a reception of a dual worldview, which is caused by the different coding of the two semiotic structural units.

A question is bound to arise: which culture do bilingual speakers represent if they speak two languages? The above-mentioned description allows us to conclude that learning bilingualism in the framework of a traditional theory of contact linguistics does not provide a comprehensive image of it. It is necessary to draw attention to a 
relatively new field of contactology - the sphere of transcultural processes. This phenomenon reflects real processes occurring in the modern world.

In modern linguistics, the understanding of the notion "transculturation" reflects a new stage in the development and study of language contacts in the era of globalization and the formation of the modern bilingualism.

The term "transculturation" was firstly coined by the Cuban anthropologist Fernando Ortiz in 1947. According to Ortiz, the process of transculturation requires synthesis of two other processes taking place simultaneously - acculturation and deculturation. Acculturation is moving away from one's own traditions in order to integrate with another culture. Deculturation is a loss or rearrangement of the given culture. The result of the synthesis of these two terms is neoculturation, which might also be called transculturation [25].

It is appropriate to give a definition of transculturation from the dictionary of linguistic terms edited by Bobakho: "Transculturation is a process and result of a voluntary or forced geographical displacement of a certain formed type of culture to remote areas where another cultural environment is either completely absent, or it is not able to provide proper resistance and influence of the 'incoming' culture" [26. P. 382].

Transculture, which appears as a result of transculturation, means "a new sphere of cultural development beyond the boundaries of the established national, racial, gender and professional cultures" by overcoming "the isolation of their traditions, language and value determinations [27. P. 419]. By the definition of Tlostanova, "transculturation as a new episteme is based on a cultural polylogue, in which, however, there should not be a complete synthesis, fusion and full cultural translation; in which the cultures meet, interact, but do not merge, retaining their right to "opacity' " [6. P. 28].

An additional explanation of the concept of transculturalism is explained in the book The Transcultural Journey by Richard Slimbach, in which the author states that transculturalism is sharing values without taking into account cultural and national limitations. At the same time, Slimbach raises transculturalism to the situation when a person in their own thinking emerges beyond the borders of the homeland, but does not lose the center of their own culture, and namely the national culture [28].

Transculturalism/transculturation involves the simultaneous coexistence of a person in different cultures, but with the preservation of the imprints of each of them. The result of transculturation is reflected in gradual changes of culture, including hybridization. Thus, transculturation, or a synonymic term "transculturation", leads to "reconciling differences" [29. P. 8]. As a result, an individual performs the role of several identities at once in both cultures. Tosltanova, on the basis of Ortiz's definition, argues that "acculturation is the acquisition of culture in a unidirectional process, and transculturation involves two phases losing or uprooting (deculturation) of a previous culture and creation of a new cultural phenomenon (neoculturation)" [7. P. 151].

However, it should be noted that, under the influence of the contacting cultures, a new worldview and new cultural ideologies are formed, which, to a certain extent, can be identified as borderline - neither here nor there, depending on the individual experience of this condition.

Transculturation implies the indirect influence and penetration of other cultural elements [7]. Transculturalism, according to Epstein, is an internal cultural multiplicity. Based on this, it is possible to state that transculturation means being both internal and external, i.e. local and global cultural multiplicity. However, this harmonious and coordinated system of culture flowing into culture could not function without intermediaries, which always turn out to be the bilingual members of the interacting communities. As stated by N. Mechkovskaya, "Even a minimal mutual understanding is impossible until either side (or at least one of the sides) makes at least one step towards their partners" [23. P. 171]. This step, consisting of mastering the main words of the contact language, has been carried out by bilinguals; i.e. the interaction of cultures (and, obviously, languages) has occurred and still occurs through the mediation of individual bilingualism of a certain number of speakers. American researchers G. Chen and W. Starosta argue, "As a culture bearer, communication influences the structure of culture, and culture necessarily manifests itself, reveals itself in our communicative models, predetermining how we should talk and behave" [30. P. 29]. Culture affects not only communication, but is also exposed to its effects, and most often it occurs when the subject of communication in one or another form of communication assimilates the norms and values of the culture [31. P. 27].

Bilingualism as a phenomenon of transcultural communication can be refined with the help of such concepts as "dynamic bilingualism" [32. P. 100] or "flexible bilingualism" [33], which is opposed to the traditional "disparate bilingualism". In contrast to the traditional dichotomy of "mixed bilingualism" and "coordinate bilingualism", which emphasizes mixing or non-mixing of two languages in the consciousness and languages of a bilingual person due to external circumstances and/or language competence. "Dynamic bilingualism" in opposition to "disparate bilingualism" reflects a fundamentally new ideology of using languages as resources in linguistic activities of bilingual people and the merge of the new contact-linguistic phenomena.

"Disparate bilingualism" occurs from the existence of isolated language systems, and therefore the main attention in the consideration of the language contact is drawn to the phenomenon of "code-alternation", which includes the cases of code-switching, i.e. transition from one language system to another in a single utterance, and "codemixing", i.e. hybridization of two language systems. However, some linguists state that there exist "other" contact language phenomena, which do not fit into this classification, especially when the boundaries between languages are not clear [34. P. 446].

The emergence and increasing dissemination of new informational and media technologies only strengthen the ongoing transcultural processes in bilingualism. Due to the level of the development of communication technologies, the style and form of communication are changing; the unwritten rules of the speech organization and speech behavior of bilinguals in internet communication extend beyond the Internet; the cultures of different nations and 
countries are wide spread and disseminated. The media of communication and information are a natural satellite of globalization, and are the ground for the formation and dissemination of transcultural communication. Here people are faced with different cultures and languages, which are being reconstructed under the influence of their "social worlds" or "social life-worlds" [35]. E-mail, TV, Internet, mobile phones and other means of communication and information are not only equipment, each of them carries the forms and patterns of our communication. Such models are confined not only to the written form, but also to the oral form.

"In transcultural communication, a process of 'crossing the border' from one cultural unity to another is at the forefront of consideration. In each transcultural interaction, a certain bilateral and reciprocal connection may be assumed; however, the main emphasis is primarily placed not on the mutual exchange of cultural elements, but on one-way 'crossing the border' from one culture to another. For example, this is clearly manifested in the sphere of mass communication ('one-way communication'), although the selective ability of the hosting side (the ability to select and choose, interpret and adjust to the culture) hinders this prospect of one-way communication" [36. P. 78].

Transcultural communication is the successful usage of languages within the repertoire of a bilingual, in which language codes for their communication purposes are violated or adapted. In transcultural communication, bilinguals use different communication strategies: the mixing and switching of language codes, borrowings and distortions, language hybridization, pidginization, and others. This process can be characterized as the collection of information in two languages and its transfer by a third, intermediate language.

As a result, a new type of bilingualism appears. This type is formed not only through direct contact of representatives of two or more cultures and languages, but also through the global Internet network. Here research perspective is shifted from a language to "language options" or "speech repertory". This type of bilingualism is subject to a limited knowledge of the language; i.e., successful communication with other bilinguals within a given society can occur not only in a foreign language, but also in the form of a mixed speech. Linguistic identity does not always coincide with ethnic identity, but together they form a unity, which is called cultural identity [37]. Moreover, a new cultural identity reflecting the trends of the globalizing world comes to be based on transcultural communication.

One of the forms of realization of transcultural communication is the recognized system World Englishes (English as a lingua franca), or the contact variant of English (in foreign literature - World Englishes Paradigm) formed in the 1970s-1980s [38]. It allows the world cultures to express their values, originality, achievements and much more through the codified variant of English. A fairly complete description of the new and old codified variants, including Irish, Singaporean, West African, East African, South Asian, and others can be found in the book Standards of English. Codified Varieties around the World by Raymond Hickey.

Another typical example of transcultural communication is the bilingual speech strategy of "code ambigua- tion" [39], which refers to the intentional creation of linguistic units with an indefinite language status blurring the boundaries between the contacting languages. Below are some examples of code ambiguity based on the examples of ironical use of Latin and Cyrillic intersection: Вееглога (beerhouse), Манхеtтен (restaurant), Баzа (business-center), Zажигалка (bar), Ніsтория, ЧеRDак (night club), Территория shoppinga (shopping complex), Бетоноff (company-manufacturer of concrete), Gатеназия (newspaper), GLAMOURный бизнес (beauty saloon), Салон tаtооировки (tattoo salon), КосметичКА (cosmetic shop), Дятлоws (animated series), Духless (book), Dovepue (the Dove soap ad on the Internet), VIPендриваться (to show off), БарбеQ (barbecue).

In this case, we are dealing with the intentional ironical use of the "blurry", "indefinite" and integrated language resources. Thus, the most important characteristic of transcultural bilingual communication is its clearly defined activity and speech-creative character. The study of transculturalism is aimed at describing a qualitatively new, creative, transformative and integrative use of all the language resources available to a bilingual, irrespective of separate languages. This fundamentally new approach to describing the language of bilinguals is reflected in the increasingly popular terms "transculturalism" or "transcultural communication".

\section{"Models of the Modern Humanitarian Education" in foreign language teaching}

Globalization, in particular the transcultural processes, could not but affect education. The model of an educated person, knowledgeable and skilled in the main spheres of life activity is already insufficient. The model of a cultural person came to replace it, which presupposes a cultural and linguistic approach to the study of objects based on transcultural approaches. This approach allows creating a system-holistic view of the world and culture, a humanization of the educational process, developing a model of high school, creating a sociocultural educational platform based on the principle "education-science-culture". In this case, practical studies, for example, works on the phenomenon of bilingualism, the possibilities and limits of multicultural education in Palestinian-Jewish schools in Israel, are of particular interest [40].

In the context of the integration of countries into world space, cooperation, and the exchange of scientific, cultural and spiritual values, an important place is given to a foreign language as a multi-level communication medium. In the modern world, a high level of knowledge of foreign languages is considered as one of the basic requirements, as an instrument of mutual understanding and respect for foreign cultures in world society. In the information society, knowledge of foreign languages implements the function of knowledge management also performing a motivational and educational function. Learning foreign languages is an element of humanitarian education. The purpose of teaching a foreign language should be to prepare students for interlinguistic and intercultural communication, a cultural dialogue and to form the student as a subject of intercultural communication. 
At present, in teaching foreign languages, two interconnected yet independent methodological concepts are actively developing: the concept of a multicultural linguistic personality [41-44] and the concept of cultural dialogue [45-47]. Based on these concepts, in the framework of modern language education, new approaches are outlined aimed at creating a multicultural basis for the content of education in teaching a foreign language, creating an integrated educational space, implementing the idea of developing education through the positions of the heritage of foreign and native languages and cultures, perceiving a foreign culture and forming multicultural educational environment.

Education and upbringing of a person who can adequately coexist in the modern polycultural environment and recognize one's own cultural identity in the surrounding sociocultural environment is one of the priorities of the modern higher education [48. Pp. 133-134].

There are several versions of the modern educational model, such as multicultural, intercultural and transcultural. All of them, one way or other, express an attitude towards the nation, state, national culture and identity, sharpening or smoothing the issue of the need of a nonmononational model of education. Particular attention to the educational models has been drawn in the work "Models of the Modern Humanitarian Education" by N. Kirabayev and M. Tlostanova. The authors believe that the mildest form of rethinking the national model is the concept of multicultural education. The meaning of multicultural education is in the integration, in which students receive the opportunity only "to taste" another culture or knowledge without going beyond their national, ethnic or other subjectivity. Multiculturalism changes neither the condescending patronizing attitude towards others, nor the rigid attitude to its exclusion from the decisionmaking sphere [49. P. 27].

Analyzing intercultural education, researchers conclude that an intercultural model of education remains within the existing disciplines, but at the same time there is a dialogue between them as they are interdisciplinary in nature. The main component in the strategy of intercultural education is not providing students with the amount of facts or some absolute knowledge, but providing them with the opportunity to learn "to be themselves", which is connected not so much with mastering positive knowledge, but with the need to correlate them with the direct personal and social experience [49. P. 29].

Tlostanova and Kirabayev consider transcultural education to be ideal in the conditions of the global domination of the corporate universalism and technocratic model of education. The goal of transcultural education is training a special worldview, in which another culture, tradition and civilization are viewed not as an obstacle that needs to be brought to a common denominator (most often, its own), but as a completely independent subject or phenomenon with its own dispositions and characteristics, with which it is necessary to engage in dialogue, egalitarian intellectual and cultural interaction [50]. This new transcultural subjectivity will inevitably go beyond national limits, but will be better adapted to the new global flows of information [51]. Upbringing and education of this kind will be based not on providing people with an amount of multicultural facts, but on cultivating their critical thinking, increasing their ethical and political responsibility, and a subtle hearing regarding the history, memory and languages [49. P. 30].

In a transcultural educational model, education and upbringing are considered as a necessary condition and the most important means of transition to the development of the heights of the human culture. "However, it is also useful to state that 'transcultural' as an adjective for learning or awareness entails more precision than solely 'cultural awareness' (as used by Tomalin and Stempleski), as the former evokes automatically the global context and a multilateral character of interactions" [1. P. 125].

\section{Conclusion}

The main conclusion that can be drawn from the conducted theoretical analysis is that the phenomenon of bilingualism is closely related to the spread of transcultural communication. On the one hand, bilingualism contributes to strengthening transcultural processes; on the other hand, bilingualism develops due to the spread of transculturalism in various spheres of life. Accordingly, the description of bilingualism presented at the beginning of the article can be complemented by the following correctional remarks.

- The repertoire of the language means of bilingual speakers is largely transcultural, i.e. is characterized by "blurring", "uncertainty", a peculiar "interlinguistic" or "extralinguistic" status; the interaction of languages and cultures is manifested through the phenomenon of "code ambiguity" and new informational and media technologies, which only strengthen the ongoing transcultural process.

- Bilingualism as a phenomenon of transculturalism can be described as "dynamic" and "flexible" in opposition to the traditional "disparate" and "segregate" understanding of bilingualism.

- Modern bilingualism can be characterized as a result of "ordinary/popular globalization", which includes a large number of people with limited, "truncated" knowledge of a foreign language.

The new transcultural paradigm broadens the horizons of opportunities for learning the phenomenon of bilingualism, fills the established concepts and terms with new meaning, and enables consideration of the linguistic contacts that previously remained out of the context of research.

The methodology of teaching foreign languages and approaches to it should be subjected to fundamental changes: a transition from a passive academic study to the practical tasks of ensuring effective communication. Currently, the langauge education system of Armenia should be oriented towards the development of multilingualism and meeting the needs of intercultural communication.

Teaching foreign languages should be reoriented to teaching communication through cultures, since language acts as a translator of culture. Considering the process of teaching foreign languages, one should pay attention to the content of intercultural education and the conditions for its implementation, since channels of communication themselves bear a cultural content. "As a result, the illusion of social solidarity is formed due to education, often 
aimed at some transethical or transnational perspective. In such a situation, the instrumental and value-related components of linguocultural dynamics can have very unexpected manifestations, which scientists and educators have yet to comprehend" [52].

The development of multilingualism is not only the provision of bilingual (multilingual) communication, but also the basis for intercultural dialogue. In our opinion, teaching three foreign languages should be implemented in the educational system, and four for minority groups. Under the conditions of institutionally subordinate multilingualism, the features of teaching a foreign language are largely conditioned by the "mobile" nature of the development of bilingualism.

\section{REFERENCES}

1. Hadaś, J. (2016) Developing transcultural awareness as a basis for intercultural dialogue: between theory and pedagogical reflection. In: Mikołajczak, A.W. \& Dymczyk, R. (eds) World in Dialogue. Intercultural Problems in the Religious, Economic, Communication and Educational Contexts. Poznań. pp. 121-138.

2. Maslova, V. (2004) Introduction to Cognitive Linguistics. Moscow: Flinta. (In Russian).

3. Likhachev, D.S. (2000) Russian Culture. Moscow: Iskusstvo. (In Russian).

4. Gachev, G.D. (2004) National images of the world. Caucasus. Moscow: Izdatelskiy servis. (In Russian).

5. Epstein, M. (2004) Space Sign: About the future of human sciences. Moscow: Novoe literaturnoe obozrenie. (In Russian).

6. Tlostanova, M. (2004) Post-Soviet literature and esthetics of transculturation. Never live, write from nowhere. Moscow: Editorial URSS. (In Russian)

7. Tlostanova, M. (2008) From the Philosophy of Multiculturalism to the Philosophy of Transculturation. Moscow: Universytet druzhbi narodov. (In Russian).

8. Malinovski, B.A. (2004) Scientific Theory of Culture. Moscow: OGI. (In Russian).

9. Zamel, V. \& Spack, R. (2004) Crossing the Curriculum: Multilingual Learners in College Classrooms. Routledge.

10. Avrorin, V.A. (1972) Bilingualism and School. Problems of Bilingualism and Multilingualism. Moscow: Nauka. pp. 49-62. (In Russian).

11. Weinreich, U. (2011) Languages in Contact. French, German and Romansh in twentieth-century Switzerland. John Benjamins Publishing Company.

12. Rosenzweig, V. (1972) Language contacts: Linguistic problems. Vol. 5. Leningrad: Nauka. (In Russian).

13. Bloomfield, L. (2012) Language. New Delhi, India.

14. Haugen, E. (1972) Language contact. The new In Linguistics: Language Contacts. Vol. VI. Moscow: Progress. pp. 61-80. (In Russian).

15. Vereshchagin, E. (2014) The psychological and methodological characteristic of bilingualism. Moscow: Berlin, Direct-Media. (In Russian).

16. Siguan, M. \& Makki, U.F. (1990) Education and bilingualism. Moscow: Pedagogika. (In Russian).

17. Szweitser, A. (1978) Contemporary Sociolinguistics: Theory, Problems, Methods. Moscow: URSS. (In Russian).

18. Yumoto, K.A. (2004) Study of Cognitive Level of Bilingual Proficiency: What Makes Balanced Bilinguals? The Journal of Asia TEFL. 1 (2). pp. 135-160.

19. Myers-Scotton, C. (2006) Multiple voices: an introduction to bilingualism. Blackwell Publishing.

20. Appel, R. \& Muysken, P. (2006) Language Contact and Bilingualism. Amsterdam University Press.

21. Zograf, A. (1998) Multilingualism. Language Studies. Moscow: Great Russian Encyclopedia.

22. Sapir, E. (2002) Selected works on linguistic and cultural studies. Moscow: Progress. (In Russian).

23. Mechkovskaya, N. (2000) Sociolinguistics. Moscow: Aspect-Press. (In Russian).

24. Wierzbicka, A. (2003) CrossCultural Pragmatics: The Semantics of Human Interaction (Mouton Textbook). De Gruyter Press.

25. Ortiz, F. (2013) Cuban Counterpoint: Tobacco and Sugar. Spanish edition. Transl. into English by Harriet de Onis. New York: Knopf Press.

26. Bobakho, V.A. \& Levikova, S.I. (2000) Culturology: basic course program, reader, glossary of terms. Moscow: Grand: Fair-Press. (In Russian).

27. Zhukova, I.N. (2013) Glossary of intercultural communication terms. Moscow: Flinta; Nauka. (In Russian).

28. Slimbach, R. (2005) The Transcultural Journey. Frontiers. The Interdisciplinary Journal of Study Abroad. 11. pp. 205-230.

29. Guilherme, M. (2015) Difference in diversity: multiple perspectives on multicultural, intercultural, and transcultural conceptual complexities. Journal of Multicultural Discourses. 10 (1). pp. 1-21.

30. Chen, G.-M. \& Starosta, W.J. (2005) Foundations of Intercultural Communication. Boston: University Press of America.

31. Grushevitskaya, T.G. (2003) Bases of Intercultural Communication. Moscow: YUNITI-DANA. (In Russian).

32. Garcia, O. (2009) Bilingual education in the 21st century: A global perspective. Malden, MA, Oxford and Chichester: Wiley-Blackwell.

33. Zhang, H. \& Chan, B. H.-S. (2015) Translanguaging in multimodal Macao posters: Flexible versus separate multilingualism. International Journal of Bilingualism. [Online] Available from: http://ijb.sagepub.com/content/early/2015/07/23/1367006915594691.abstract (Accessed: 12.04.2017). DOI: 10.1177/1367006915594691

34. Auer, P. (2001) Code-switching: Discourse Models. In: Mesthrie, R. (ed.) The Concise Encyclopedia of Sociolinguistics. Oxford: Elsevier Science Ltd. pp. 443-446.

35. Strauss, A. (2003) Qualitative Analysis for Social Scientists. Cambridge University Press.

36. Shamne, N. (2003-2004) Intercultural and transcultural communication: to the definition of concepts. Vestnik Volgogradskogo gosudarstvennogo universiteta. Yazykoznanie - Science Journal of Volgograd State University. Linguistics. Ser. 2. Vol. 3. pp. 73-80. (In Russian).

37. Savchenko, I.A. (2010) Linguistic identity and sociocultural conditions for the development of ethnic communities. Vestnik LGU im. A.S. Pushkina - Bulletin of Leningrad State University named after A.S. Pushkin. 3. pp. 281-296. (In Russian).

38. Proshyna, Z. (2010) The variance of the English language and intercultural communication. Personality. Culture. Society. XII:2 (55-56). pp. 242252.

39. Moody, A. \& Matsumoto, Y. (2003) Don't touch my moustache: Language blending and code-ambiguation by two J-pop artists. Asian Englishes. 6 (1). pp. 4-33.

40. Bekerman, Z. (2004) Potential and Limitations of multicultural education in conflict-ridden areas: Bilingual Palestinian-Jewish schools in Israel. Teachers College Record. 106 (3). pp. 574-610.

41. Isaev, E.A. (2015) Student's linguistic personality and multicultural self-organization through foreign language teaching. Language and Culture. 1 (29). pp. 96-103. (In Russian).

42. Gural, S.K. \& Pavlenko, E.I. (2011) Formation of Multicultural Multilingual Personality as a new type by third foreign language. Language and Culture. 2 (14). pp. 115-120. (In Russian).

43. Kuklina, S.S. et al. (2017) Educational autonomy of a multicultural linguistic personality. Revista Espacios. 38 (40). p. 24

44. Savchenko, I.A. (2013) Sociocultural aspects of the modern educational process. Training, Testing and Evaluation. 13. pp. 215-217. (In Russian).

45. Sysoyev, P.V. (2018) Revising a structure of intercultural competence: training intercultural interaction in the conditions of "dialogue of cultures" and "non-dialogue of cultures". Language and Culture. 43. pp. 261-281. DOI: 10.17223/19996195/43/16

46. Rostova, E. \& Shamin, S. (2013) Dialogue of cultures and comparison of cultures in both modern multicultural society and educational process. Ethnic Dialogues. 1 (42). pp. 82-89. (In Russian). 
47. Millrood, R.P. \& Maksimova, I.R. (2017) Learner bilingualism: Yesterday, Today and Tomorrow. Language and Culture. 37. pp. 185-204. (In Russian). DOI: 10.17223/19996195/37/13

48. Balashov, E., Pasichnyk, I. \& Kalamazh, R. (2016) Intercultural Components of Student Self-Realization in International Volunteering Programmes. Annual of Social Work. 23 (1). pp. 123-139. DOI: 316.723 : 364.467-057.87

49. Kirabayev, N. \& Tlostanova, M. (2009) Models of modern humanitarian education. Higher Education in Russia. 1. pp. 24-32. (In Russian).

50. Soboleva, A.V. \& Obdalova, O.A. (2015) Cognitive readiness for intercultural communication as an essential component of intercultural competence. Language and Culture. 1 (5). pp. 55-62. (In Russian). DOI: 10.17223/19996195/29/16

51. Obdalova, O.A. \& Odegova, O.V. (2018) Intercultural and interlingual communication as a new reality in the context of globalization. Vestnik Tomskogo gosudarstvennogo universiteta. Filosofiya. Sotsiologiya. Politologiya - Tomsk State University Journal of Philosophy, Sociology and Political Science. 44. pp. 70-81. (In Russian). DOI: 10.17223/1998863X/44/7

52. Savchenko, I.A. \& Vikulina, M.A. (2018) Linguocultural dynamics and educational process. Language and Culture. 43. pp. 199-216. (In Russian). DOI: 10.17223/19996195/43/13

Received: 10 December 2020

Bilingualism as a Phenomenon of Transcultural Communication in Foreign Language Teaching

Vestnik Tomskogo gosudarstvennogo universiteta - Tomsk State University Journal, 2021, 463, 188-195.

DOI: $10.17223 / 15617793 / 463 / 24$

Irina A. Savchenko, Linguistics University of Nizhny Novgorod (Nizhny Novgorod, Russian Federation); Nizhny Novgorod Academy of the Ministry of the Internal Affairs of the Russian Federation (Nizhny Novgorod, Russian Federation). E-mail: teosmaco@rambler.ru

Svetlana S. Barseghyan, Vanadzor State University (Vanadzor, Republic of Armenia). E-mail: svetlana-barsegyan@yandex.ru

Билингвизм как феномен транскультурной коммуникации в процессе преподавания иностранного языка Вестник Томского государственного университета, 2021, 463, 188-195

Савченко Ирина Александровна, Нижегородский государственный лингвистический университет им. Н.А. Добролюбова; Нижегородская Академия МВД России (Нижний Новгород, Российская Федерация). E-mail: teosmaco@rambler.ru

Барсегян Светлана Сережаевна, Ванадзорский государственный университет им. О. Туманяна (Ванадзор, Республика Армения). E-mail: svetlana-barsegyan@yandex.ru

Ключевые слова: двуязычие; транскультурация; глобализация, языковые контакты; транскультурная коммуникация; мультикультурная модель образования; межкультурная модель образования; транскультурная модель образования.

В статье рассматриваются тенденции развития языкового образования в процессе преподавания иностранных языков в условиях глобализации и информатизации общества, а также собственно лингвистические интерпретации билингвизма, его широкое и узкое понимания, деятельностный, речетворческий аспекты транскультурации. Объектом изучения является вопрос о соотношении транслингвизма и билингвизма как ключевых понятий современной лингвистической контактологии, а также транскультуральное коммуникативное поведение и творческий характер транслингвальной речи билингвов. В научно-исследовательской работе были применены классические методы лингводидактики, педагогики и языкознания, такие как аналогия, обобщение и сравнение; использовались методы социокультурного, системного, структурно-функционального анализа, нарративного анализа и описания. Языковым материалом данного исследования послужили примеры названий кафе, ресторанов, разных салонов и компаний. При исследовании подобных названий внутригородских объектов авторы применили метод анализа и синтеза информации, а также метод изучения, обобщения и сравнения теоретического и практического материала по заданной теме. Поскольку идеологической основой транскультурации является эпистемологическое переосмысление понятий традиционной культуры, в данном исследовании авторы трактуют транскультурную коммуникацию как процесс успешного использования языков репертуара билингва, при котором порою нарушаются или приспосабливаются языковые коды для своих коммуникативных целей. Типичным примером транскультурной коммуникации может послужить билингвальная речевая стратегия «кодовой амбигуации». В статье приводятся примеры игрового использования пересечений кириллицы и латиницы: GLAMOURный бизнес (beauty saloon), Салон tatoочровки (tattoo salon), КосметичKA (cosmetic shop) (KA в армянском языке обозначает «наличие чего-либо») и др. Мы рассматриваем этот процесс как сбор информации на двух языках и передачу ее посредством третьего, промежуточного языка. Вследствие этого возникает новый тип билингвизма. В результате исследования мы пришли к следующему выводу: репертуар языковых средств билингвов в значительной степени транскультурален, т.е. характеризуется «размытостью», «неопределенностью», своеобразным «межъязыковым» или «внеязыковым» статусом. Вместе с тем надо отметить, что в условиях институционально подчиненного многоязычия особенности преподавания иностранного языка в большинстве своем обусловлены динамичным характером развития двуязычия.

Статья представлена научной редакцией «Педагогика» 10 декабря 2020 г. 